Boletín de la Sociedad Geológica Mexicana

VOLUMEN 64, NÚM. 1, 2012, P. 21-35

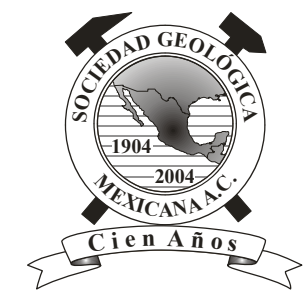

\title{
Evidence for isovolumetric replacement in some Terra Rossa profiles of northern Jordan
}

\author{
Bernhard Lucke ${ }^{1, *}$, Helga Kemnitz², Rupert Bäumler ${ }^{1}$ \\ ${ }^{1}$ Institute of Geography, Friedrich-Alexander University Erlangen-Nürnberg, Kochstr. 4/4, 91054 Erlangen, Germany \\ ${ }^{2}$ Helmholtz-Zentrum Potsdam, German GeoResearchCentre (GFZ), Section 3.1, Telegrafenberg, 14473 Potsdam, Germany \\ *blucke@geographie.uni-erlangen.de
}

\begin{abstract}
We investigated the rock-soil transition zones of three different Terra Rossa profiles near the ancient site of Abila, in northern Jordan, in order to demonstrate the possibility of a metasomatic origin for these soils using a scanning electron microscope (SEM) equipped with an energy-dispersive system (EDS). The field interpretation suggested that the first Terra Rossa might partially have formed by isovolumetric replacement, the second appeared to represent mainly the residue of the underlying limestone, and the third seemed to be derived from colluvial material. However, all investigated rock-soil transition zones showed microfossils that had partially been replaced by clay, which could be geochemically confirmed using EDS. The replacement matrix was free of detrital clay and revealed a jelly-like, amorphous structure. Large phyllosilicates, some rare feldspars, and heavy minerals that occurred throughout the investigated rock-soil transition zones are probably remains of sandy interlayers in the weathered limestone. We conclude that isovolumetric replacement contributes to Terra Rossa formation in northern Jordan although it is not yet possible to quantify the extent of its contribution or the sources that supply the elements triggering the pressure-driven growth of clay minerals.
\end{abstract}

Keywords: isovolumetric replacement, Terra Rossa, metasomatism, micromorphology, rock-soil transition.

\section{Resumen}

Investigamos las zonas de transición roca-suelo de tres diversos perfiles de Terra Rossa cerca del sitio antiguo de Abila, en Jordania del norte, para comprobar el posible origen metasomático de estos suelos, usando un microscopio electrónico de exploración (SEM) con el sistema energía-dispersivo (EDS). La interpretación en el campo sugirió que la primera Terra Rossa pudo haberse formado parcialmente por el reemplazo isovolumétrico, el segundo parece representar, primeramente, el residuo de la caliza subyacente, y el tercero parece ser de origen coluvial. Sin embargo, todas las zonas investigadas en transición roca-suelo presentan microfósiles que habian sido substituidos parcialmente por la arcilla, lo cual se confirmó geoquímicamente usando EDS. La matriz de reemplazo se encontraba libre de la arcilla detrítica y reveló una estructura amorfa, similar a gel. Grandes filosilicatos, algunos raros feldespatos y minerales pesados que se encontraron en las zonas investigadas de transición roca-suelo, probablemente son restos de capas arenosas, intercaladas en la caliza. Concluimos que el reemplazo isovolumétrico contribuye a la formación de Terra Rossa en Jordania del norte, aunque todavía no es posible cuantificar el grado de su contribución, o las fuentes que suministran los elementos que accionan el crecimiento por presión de los minerales de la arcilla.

Palabras claves: reemplazo isovolumétrico, Terra Rossa, metasomatismo, micromorfología, transición roca-suelo. 


\section{Introduction}

Clay-rich red soil on limestone, termed "Terra Rossa" or "Roterde" in old classification systems (whether decalcified or not, see Leiningen, 1930; Reifenberg, 1947), is widespread in areas with Mediterranean climate, and is the most common type of paleosol in the Middle East. Despite its ubiquitous presence, dissent still exists about the fundamentals of the red soil's parent material and genesis, which limits its interpretability as paleoenvironmental proxy. Zippe (1854) and Leiningen (1930) suggested that the red clay resembles the residue of calcareous rocks: Terrae Rossae could be the result of limestone dissolution by meteoric water. This model was supported by studies from Slovakia (Bronger et al., 1984), Italy (Moresi and Mongelli, 1988), China (Shijie et al., 1999, Ji et al., 2004a, 2004b), and Turkey (Temur et al., 2009), where the mineral assemblies and geochemistry of the red soils were largely identical to the non-calcareous residue of the underlying limestones. In Germany, the residual theory is the most accepted explanation of Terra Rossa genesis (Scheffer and Schachtschabel, 1998).

However, as already Leiningen (1915) pointed out, the mineral assemblies of Terrae Rossae often differ from the bedrock residue. In addition, it could be necessary to dissolve large amounts of limestone (from several meters to many decameters, depending on the purity of the limestone) to form one meter of soil, which would require very long time periods of geomorphologic stability and/or intense weathering. Therefore Leiningen (1915) suggested that allochthonous sediments, including aerosols, contributed to the genesis of many Terrae Rossae. Yaalon and Ganor (1973) proposed that atmospheric Saharan dust settling with precipitation is the main parent material of Terra Rossa in the Near East. Studies in Indiana, U.S.A. (Ruhe and Olson, 1980), Croatia (Durn et al., 1999), the West Indies (Muhs, 2001, Muhs et al., 2007, Prognon et al., 2011), Wisconsin, U.S.A. (Stiles and Stensvold, 2008), and Spain (Muhs et al., 2010) supported the idea of allochthonous parent material since the geochemical composition of the investigated Terrae Rossae differed significantly from the underlying limestones. In the case of Israel, Danin et al. (1982) found fossil marks of lichen on limestone under a Terra Rossa, indicating that the rock had once been exposed to sunlight before being covered by soil. More detailed overviews about the "residual" and "aeolian" theories of Terra Rossa formation and their limitations can be found in Merino and Banerjee (2008) and Lucke (2008).

As some investigations found clear evidence for inheritance from the bedrock while others proved an allochthonous origin, it is possible that there is no universal explanation for the origin of Terrae Rossae. Some studies found that both of the above mentioned parent materials, allochthonous (aeolian) sediments and residues produced by in-situ weathering of carbonate rocks, contributed to Terra Rossa development at locations in Spain (Delgado et al.,
2003, González Martín et al., 2007), Morocco (Bronger and Bruhn-Lubin, 1997), Mexico (Cabadas-Báez et al., 2010; Cabadas et al., 2010), Jordan (Schmidt et al., 2006; Lucke, 2008) and China (Feng and Zhu, 2009). In the case of Jordan, soil geochemistry and the distribution of Terrae Rossae and Red Mediterranean Soils with regard to the bedrock indicated that these soils cannot be the exclusive product of aeolian deposition or carbonate rock weathering, but that the underlying rocks and allochthonous sources must play a role in their formation (Schmidt et al., 2006; Lucke, 2008).

In this context, Blanck $(1915,1916,1926)$, Blanck and Scheffer (1926), Blanck et al. (1926, 1928), and Blanck and Oldershausen (1936) suggested that metasomatism offers an explanation for the distribution of Terrae Rossae in Europe. Based on Regny's (1904) considerations on the role of iron precipitation from Terra Rossa soil water, Blanck's (1915) model of iron diffusion into the pores of calcareous rocks assumed that iron precipitation out of the soil water led to the replacement of limestone in a pressure-driven reaction which produced acids that further dissolved calcium carbonate, essentially resembling processes of laterite formation. The iron would be supplied from allochthonous sources: overlying soil horizons, colluvial or aeolian sediments (Blanck, 1915, 1926).

According to Blanck $(1915,1916)$ and Blanck et al. (1926), the small humus contents are decisive for the dominating formation of red soils on calcareous rocks in Mediterranean climates, and explain why red soils are largely absent on calcareous rocks of temperate zones. In areas with soils rich in humus, like calcareous rocks in temperate zones, the soil water is saturated with organic acids providing a "colloid" that prevents iron from precipitating even when in contact with calcareous rocks. In contrast, the iron must precipitate when reaching the calcareous rocks in Mediterranean climates due to the much lower humus content of these soils (Blanck, 1915). Regarding red soil horizons under brown soils at the contact zone with the underlying calcareous rocks as reported e.g. from northern Italy or central Germany, Blanck (1926), Blanck et al. (1928), and Blanck and Oldershausen (1936) suggested that these represent the result of iron illuviation from the upper brown soil horizons where the iron precipitated in contact with the calcareous rocks.

Reifenberg $(1927,1947)$ argued that the necessary iron and clay were not supplied by external sources, but by ascending water from the underlying calcareous rocks while silicic acids, and not humus, provided the "colloid" that prevented flocculation of sesquioxides and growth of minerals before ascension of the ions into the rock pores and the soil. Although he could not conclusively prove this model, Reifenberg (1927) considered Terrae Rossae a precursor of laterite formation too.

Using a SEM for micromorphology, Lijun and Jingyang (2002) reported metasomatic relic bedding structures of the underlying limestone in Terra Rossa in south China and 
observed how primary calcite was replaced by illite. Merino and Banerjee (2008) identified a metasomatic front at the rock-soil transition zone of a Terra Rossa in Bloomington, Indiana, U.S.A., and developed a thermodynamic model describing the replacement reaction. Their model suggests that a superconcentration of cations in the rock pore solution would not only trigger clay mineral growth and a subsequent pressure-driven replacement of the limestone but also release acids, which could explain the association of Terra Rossa and karst. The core evidence for such reactions are morphological details of the limestone preserved near the rock-soil contact zone ("shadows" of partially replaced minerals and microfossils). According to Merino and Banerjee (2008), the cations necessary for the superconcentration in the rock pores could be supplied by dust that is deposited and dissolved at the surface, and transported by meteoric water into the rock pores. This way, guest (clay) minerals, geochemically completely different to the host rock, could metasomatically grow and isovolumetrically form Terra Rossa out of the limestone, related to but not directly resembling allochthonous material brought with aerosols.

A metasomatic genesis could explain many open questions of Terra Rossa distribution in Jordan, but so far only a few studies have attempted to study the rocksoil transition zone of Terrae Rossae and the underlying limestones. In this paper, we focus on the basic question whether evidence for metasomatic reactions can be found in Terrae Rossae in Jordan. Since "shadows" of replaced microfossils or minerals at the rock-soil transition seem to be the only evidence that can prove or disprove the idea, this paper discusses mainly the micromorphology of three Terra Rossa profiles in Jordan after presenting basic chemical and physical properties of some of the studied soils. In order to check the geochemistry of the "metasomatic reaction front", we used a scanning electron microscope equipped with an energy-dispersive system, which to our knowledge, is the first study of its kind ever conducted.

\section{Test sites and methods}

We studied three different Terra Rossa profiles near the ancient site of Abila in northern Jordan, close to the modern city of Irbid (Figure 1). The landscape of the area consists of a plateau of horizontally layered, banked limestones (Belqa-group according to Bender, 1974), which is nearly continuously covered by Terra Rossa, and dissected by several steep valleys (for more details see: Lucke, 2008). The area enjoys a Mediterranean climate with hot, dry summers and moist winters, and receives about $400 \mathrm{~mm}$ of precipitation (annual average). Despite the uniform appearance of the plateau's soil cover, the present Terrae Rossae show some variations and we selected our test sites accordingly: the first site appeared visually qualified for metasomatic processes since it exhibited a "bleached zone" similar to the one described by Merino and Banerjee (2008); the second seemed characterised by saprolite and thus qualified for a residual origin; and the third appeared to have formed out of allochthonous sediments.

Our first test site (AB-profile, samples "AB DS" 0, 1, and, 2, location: N $32^{\circ} 42^{\prime} 54.0^{\prime \prime}$, E $35^{\circ} 52^{\prime} 28.8^{\prime \prime}$, Figure 2) was exposed by a newly constructed road leading to the Unity Dam in the Yarmouk valley between Jordan and Syria. Olives were planted at the top, and roots present throughout the profile, reaching into fissures of the limestone. At the bottom of the profile, a "bleached zone" was present at the rock-soil transition that appeared similar to the one described by Merino and Banerjee (2008), although being significantly larger. Schmidt et al. (2006) and Lucke (2008) interpreted the lower $250 \mathrm{~cm}$ of the profile as in-situ Terra Rossa paleosol preserved in a karst pocket, while the upper $100 \mathrm{~cm}$ showed signs of strong fluvial re-deposition. In the "bleached zone", strongly weathered basalt boulders "floating" at the rock-soil transition were observed, evidence of a once larger distribution of lava flows (Figures 2 and 3).

Micromorphological samples were taken (i) from the transition of the unweathered bedrock to the bleached zone apparently still consisting of rock (AB DS 0), (ii) from the transition of this zone to an area apparently consisting of light-coloured Terra Rossa soil material (AB DS 1), and (iii) from the transition between the light and fully red coloured Terra Rossa (AB DS 2). In order to check the basalt boulders as possible additional source material for the soil development, sample "AB DS basalt" was taken from the bleached zone in contact with the basalt.

The collection of thin section samples was challenging: thin but stable metal containers (well-cut empty cans) were placed on the transition of soil and rock and the samples slowly cut out with a knife. This did, however, not work with the solid basalt boulder in the AB-profile, and therefore only the clay in direct contact with the basalt was sampled. After freeze drying, the samples were stabilized using Araldite A2020 epoxy resin. The thin sections were diamond-polished and carbon coated. After optical analysis, microanalysis was done with a high resolution field-emission scanning electron microscope (FESEM; Carl Zeiss Ultra 55 Plus), equipped with an energy-dispersive system by Thermo Fisher Scientific.

General soil analyses of seven bulk soil and one rock sample determined calcium carbonate and organic carbon contents with a Leco TrueSpec C-N analyser measuring samples before and after ignition of organic matter. Pedogenic iron oxides were extracted with sodium dithionite at room temperature according to Holmgren (Schlichting et al., 1995). Weakly crystallized oxides were extracted in the dark using buffered ( $\mathrm{pH} 3.25)$ oxalate solution according to Schwertmann (Schlichting et al., 1995). The iron, manganese and aluminium contents were measured with an atomic absorption spectrometer (M-series by Unicam, thermo-flame-spectrometer). Particle sizes were analysed after removing $\mathrm{CaCO}_{3}$ with $10 \%$ hydrochloric 


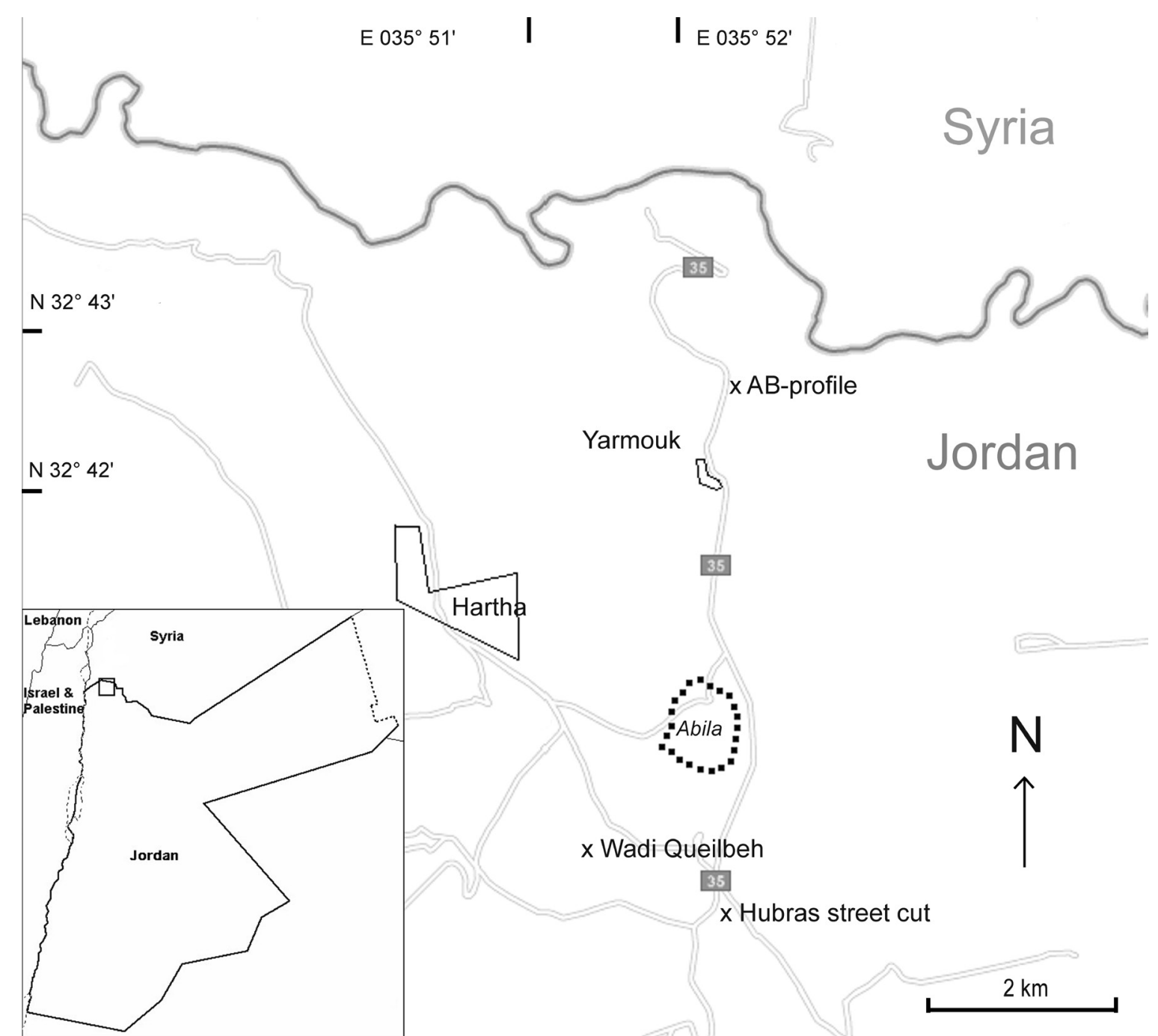

Figure. 1: Map showing the three investigated soil profiles. The border between Jordan and Syria follows the Yarmouk river. Major roads, the villages Hartha and Yarmouk, and the ancient site of Abila (dotted line) have been sketched. The small box in the lower left shows the approximate location of the investigation area in Jordan and the region.

acid. Wet sieving determined the sand fraction according to DIN 19683 (1973), while the smaller particles were analysed with the sedimentation analysis according to Köhn (Schlichting et al., 1995). Total element contents were examined with X-ray fluorescence analysis (XRF) using a wavelength-dispersive spectrometer type PW 2400 and preparing samples according to DIN 51001 (2003). Magnetic susceptibility was studied using a Kappabridge KLY-3S magnetic susceptibility meter $(875 \mathrm{~Hz})$. Specific surfaces were measured using the BET-procedure with ASAP 2020 MP (Micromeritics), and clay minerals were determined using a D $5000 \mathrm{X}$-ray diffractiometer. The examination focused on the angle range of $2-33^{\circ} 2 \theta$, and the approximate quantification of clay minerals was conducted according to the Rietveld method (Rietveld, 2010) which statistically eliminates amorphous minerals (assuming that all are crystalline).

The second test site was exposed at a street leading to the village of Hubras (sample "Hubras street cut DS", location N 32॰ 40'04.9”, E 35० 50' 46.7”, Figure 4), under an agricultural field planted with olives and wheat. Roots were present throughout the profile, reaching into the fissures of the limestone. This profile did not show a bleached zone: the rock-soil transition merely looked like saprolite as would be expected from the "residual" theory of Terra Rossa formation. In this profile, one thin section sample was collected from the soil-rock transition, while calcium carbonate content and texture were determined with the methods described above of four bulk soil samples.

The third test site was a Terra Rossa paleosol in Wadi Queilbeh that formed on strongly cemented, hard and well-rounded wadi gravel (samples "Q rock transition" 1 and 2, location N $32^{\circ} 40^{\prime}$ 17.6”, E $35^{\circ}$ 51' 51.5”, Figure $5)$. The paleosol had later been buried by huge layers of gravel, rubble, and other sediments in the valley's recent history. This profile showed neither a "bleached zone" 


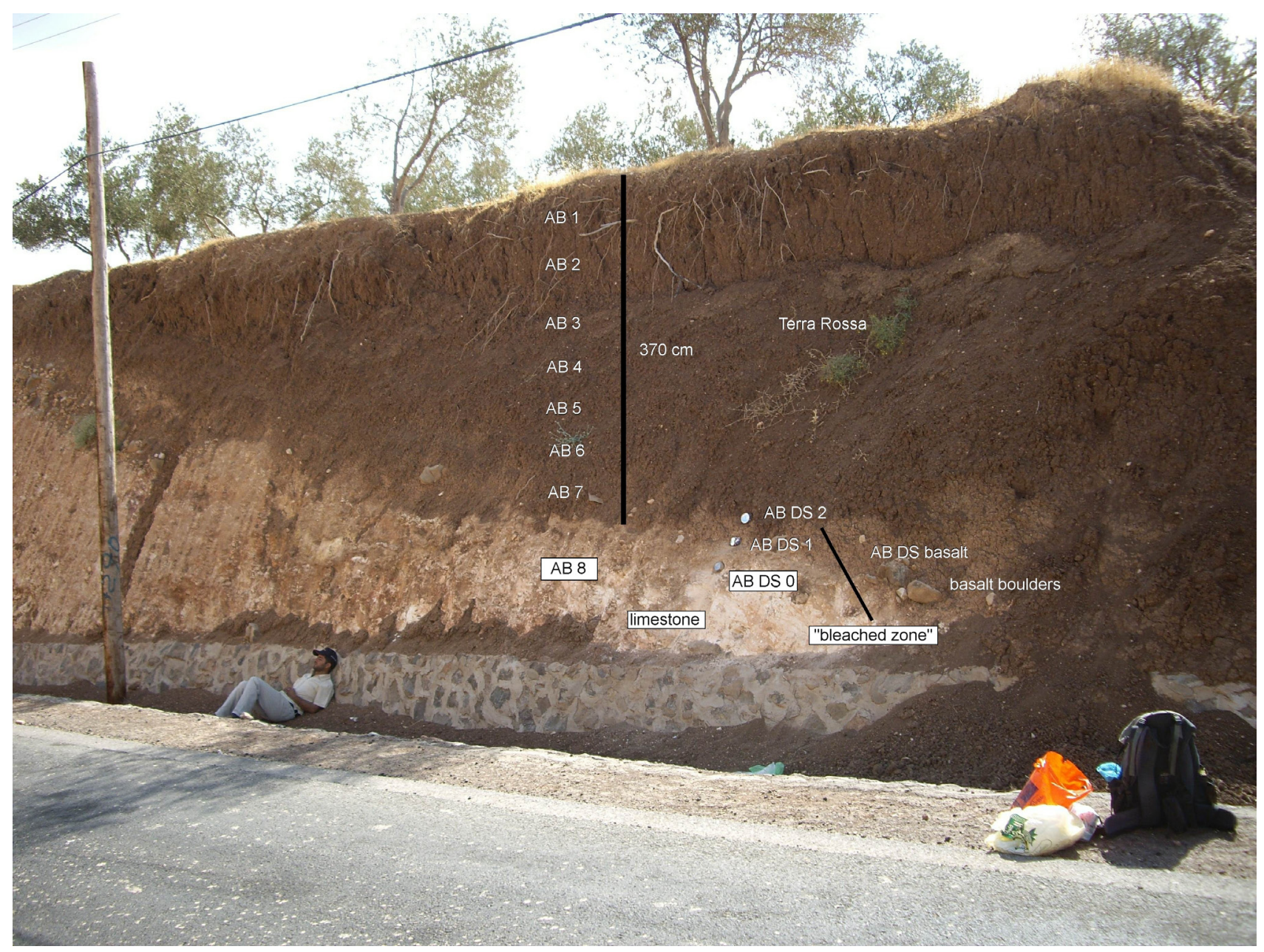

Figure 2: The "AB"-profile exposed along the street cut leading to the unity dam. The approximate sampling locations of samples AB 1-8 have been marked along the $370 \mathrm{~cm}$ deep profile (scale marked with black bar). The thin section samples AB DS 0-2 and "AB DS basalt", and the "bleached zone" at the transition from rock to soil have been marked as well. Note the basalt boulders to the right in the "bleached zone".

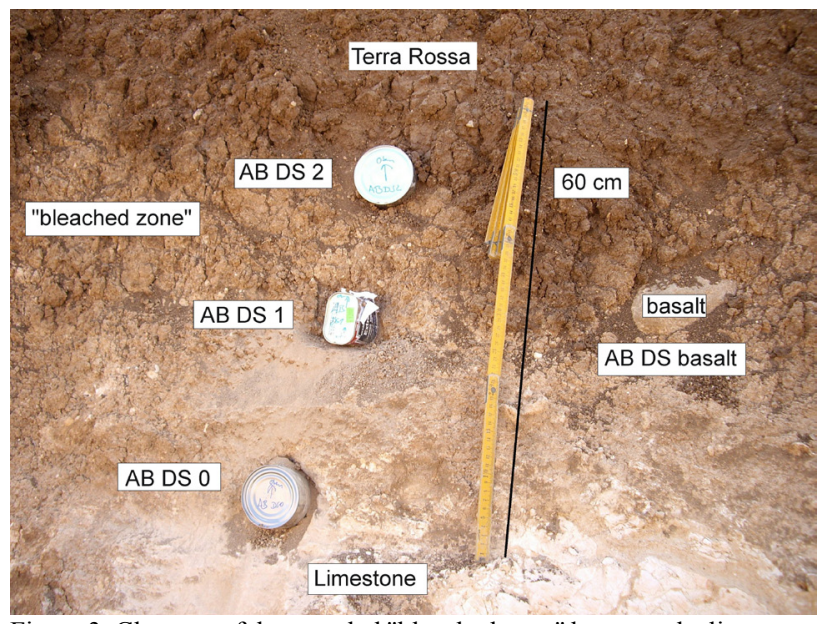

Figure 3: Close-up of the sampled "bleached zone" between the limestone bedrock and fully developed Terra Rossa at the "AB"-profile. Note the basalt boulder to the right of the meter, which measures $60 \mathrm{~cm}$. The sampling containers were placed at areas of colour changes in the "bleached zone", from white to rosé to red. Sample "AB DS basalt" was taken from clay adjacent to the basalt since this rock was too hard to be included in the sampling.

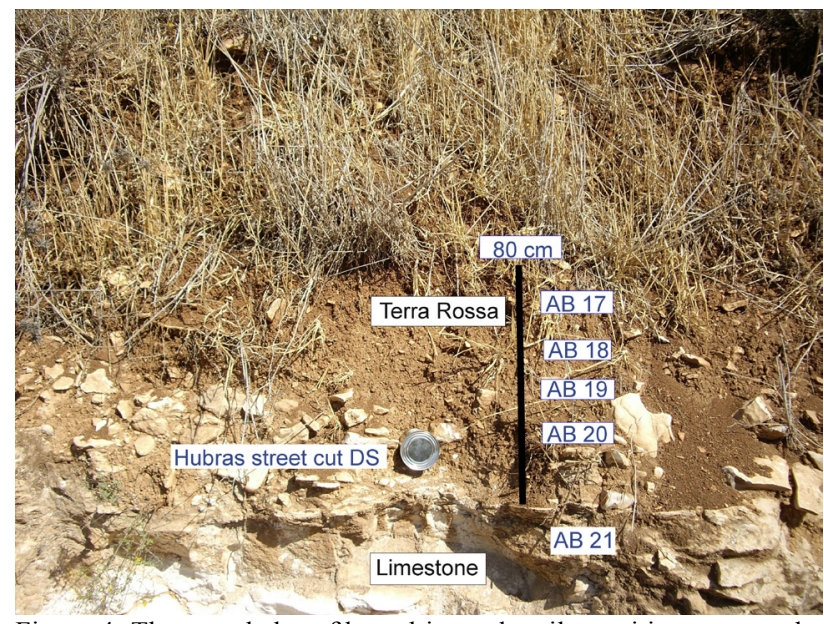

Figure 4: The sampled profile and its rock-soil transition zone at the street cut near Hubras. The black bar gives the scale $(80 \mathrm{~cm})$, and the bulk samples AB 17-21 as well as thin section sample "Hubras street cut DS" have been marked. The sampling container illustrates how the sampling attempted to catch the rock-soil transition in an area apparently characterized by saprolite. 


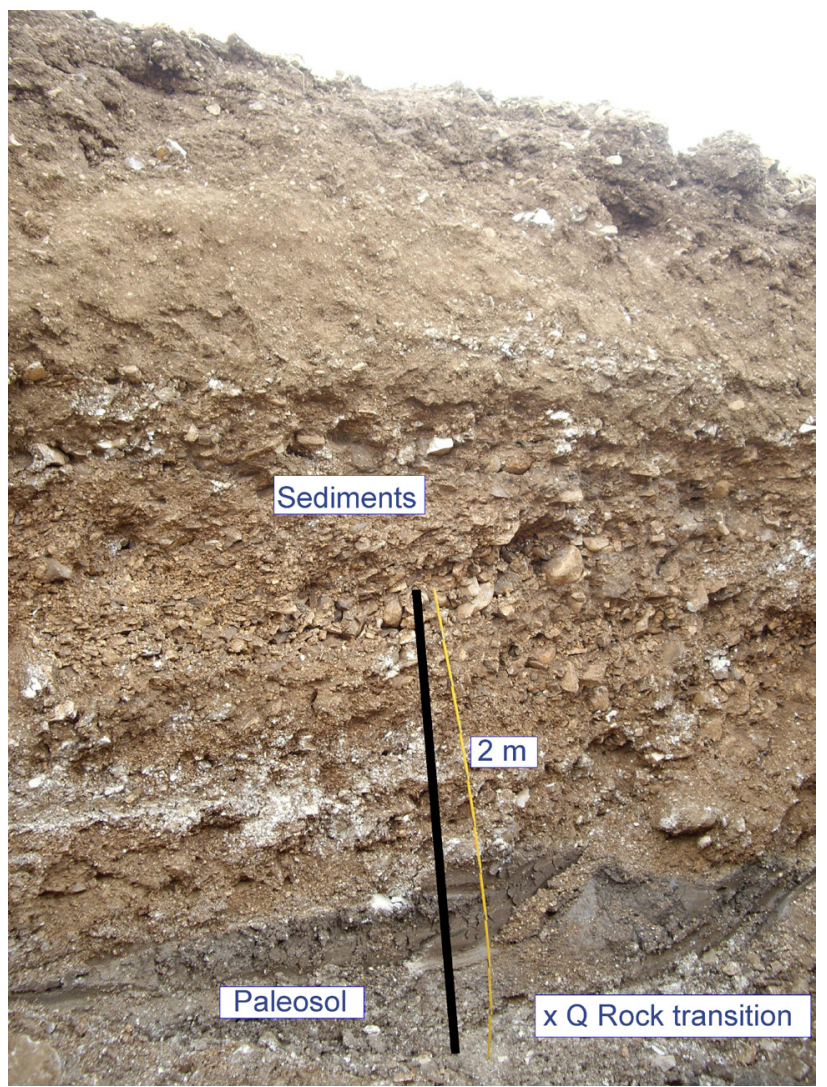

Figure 5: The sampled valley fill with sediments and a paleosol in Wadi Queilbeh. Unfortunately no close-up photo of the rock-soil transition and the paleosol is available. The meter and black bar measure $2 \mathrm{~m}$. The sampling location of samples "Q rock transition" 1 and 2 has been marked. In this area the paleosol showed an apparently "sharp" transition to wellrounded, cemented gravels.

nor "saprolitic" weathering of bedrock. Instead, it was characterized by an apparently sharp transition between soil and the cemented wadi gravel as would be expected according to the "aeolian" theory that considers Terra Rossa derived from allochthonous material. A few roots were present in the paleosol. Bulk samples from the upper part of the profile had previously been studied by Lucke (2008). Since the allochthonous origin of the largest part of the profile seemed clear, we investigated only the micromorphology of the paleosol-rock contact zone.

\section{Results}

\subsection{Results of bulk soil analysis}

Silicium, aluminium, pedogenic iron, and clay contents are highest in the lowest part of our first investigation site, the AB-profile (Table 1), while calcium carbonate and sand contents increase towards the top, supporting the field impression of additions of substrate rich in primary $\mathrm{CaCO}_{3}$ in the upper part of the profile. This is further corroborated by magnetic susceptibilities (Table 1), the specific and micropore surface areas, and the $\mathrm{Ba} / \mathrm{Sr}$ ratio, which all increase towards the bottom of the profile. In sample $A B 3$, the increase of organic matter could indicate a buried surface, which again points to the deposition of allochthonous material in the upper part. The increase of oxalate-extractable aluminium $\left(\mathrm{Al}_{\mathrm{o}}\right)$ towards the lower part of the profile points to a higher Al-activity in the soil solution and therefore a higher share of amorphous mineral fractions.

We did not evaluate the particle sizes of the underlying bedrock residue according to the example of Durn et al. (1999) because it is unclear which specific kind of carbonate rock provided the residue that led to soil formation. Lucke (2008) estimated, from sample AB 8, that 6 - $9 \mathrm{~m}$ of limestone would have to be dissolved at the studied site to form one meter of purely residual soil, but the purity of the limestone varies greatly within the same geological units (see Bender, 1974). In order to estimate the possible contribution of rock residue to the soil, we selected one sample of relatively impure chalk from a nearby outcrop (TZ 54). It shows that the soils and the rock residue are characterized by similar silt contents, while the sand content of the relatively impure chalk is higher. Although the smaller grain-sizes of the soils point to a pedogenic weathering out of the rock, the similar silt contents open the possibility that this difference might merely be attributed to primary differences of the more resistant quartz-bearing sand-sized fractions.

The ratio of pedogenic to total iron $\mathrm{Fe}_{(\mathrm{d} / \mathrm{t})}$ does not fit the pattern of decreasing soil maturity towards the top. According to Lucke (2008), the ratio of dithionite-extracted to total manganese $\mathrm{Mn}_{(\mathrm{d} / \mathrm{t})}$ was sometimes well-suited to characterize soil development intensity in northern Jordan: this seems not fully true for the present profile. Similar to the the $\mathrm{Fe}_{(\mathrm{d} / t)}-$ ratio, the $\mathrm{Mn}_{(\mathrm{d} t \mathrm{t})}$-ratio shows no clear trend.

Since most cations in the soils of northern Jordan are enriched in comparison to the underlying rocks (Lucke, 2008), a base-accumulation-index was calculated $(\mathrm{SiO}$ $\left.\left.{ }_{2}+\mathrm{TiO}_{2}+\mathrm{Al}_{2} \mathrm{O}_{3}+\mathrm{Fe}_{2} \mathrm{O}_{3}+\mathrm{MnO}+\mathrm{MgO}+\mathrm{Na}_{2} \mathrm{O}+\mathrm{K}_{2} \mathrm{O}\right) / \mathrm{CaO}\right)$ involving all ions that show frequent enrichment, divided by calcium which alone, in comparison to the underlying rocks, was depleted in all soils studied by Lucke (2008). The index suggests that the strongest enrichment of cations took place in the lowest part of the profile where, according to the field impression, the strongest weathering should have taken place.

The very homogeneous $\mathrm{Ti} / \mathrm{Zr}$-ratios point to a common parent material of the whole Terra Rossa profile, but differ significantly from the rock samples, in particular the underlying rock. The clay mineral assemblies support the impression that allochthonous material is present in the ABprofile. The considerable amount of vermiculite, counted by Molinaroli (1996) as mineralogical marker of Saharan dust in the Eastern Mediterranean, cannot be explained by weathering out of the underlying rock or by pedogenic formation from illite. 
Table 1. Bulk soil analyses of the AB-profile and sample TZ 54 from a nearby chalk surface outcrop. $\mathrm{Fe}_{(\mathrm{d} / \mathrm{t})}$ and $\mathrm{Mn}_{(\mathrm{d} / \mathrm{t})}$ represent the ratios of dithioniteextractable to total iron and manganese. $\mathrm{Al}_{0}$ represents the oxalate-extractable aluminium. The base accumulation index was calculated: $\left(\mathrm{SiO}_{2}+\mathrm{TiO}_{2}+\right.$ $\left.\mathrm{Al}_{2} \mathrm{O}_{3}+\mathrm{Fe}_{2} \mathrm{O}_{3}+\mathrm{MnO}+\mathrm{MgO}+\mathrm{Na}_{2} \mathrm{O}+\mathrm{K}_{2} \mathrm{O}\right) / \mathrm{CaO}$.

\begin{tabular}{|c|c|c|c|c|c|c|c|c|c|}
\hline $\begin{array}{c}\text { Sample } \\
\text { No. } \\
\end{array}$ & Deptl & $(\mathrm{cm})$ & $\begin{array}{l}\mathrm{SiO}_{2} \\
(\%)\end{array}$ & $\begin{array}{c}\mathrm{Al}_{2} \mathrm{O}_{3} \\
(\%) \\
\end{array}$ & $\begin{array}{c}\text { Dithionite soluble } \\
\text { iron } \\
(\mathrm{mg} / \mathrm{g}) \\
\end{array}$ & $\begin{array}{c}\mathrm{CaCO}_{3} \\
(\%) \\
\end{array}$ & $\begin{array}{l}\text { Clay } \\
(\%) \\
\end{array}$ & Silt (\%) & $\begin{array}{c}\text { Sand } \\
(\%)\end{array}$ \\
\hline $\mathrm{AB} 1$ & 5 & & 28.7 & 8.3 & 10.3 & 44 & 69 & 22 & 9 \\
\hline $\mathrm{AB} 2$ & 1 & & 27.4 & 7.8 & 7.5 & 48 & 68 & 21 & 11 \\
\hline $\mathrm{AB} 3$ & 1. & 0 & 34.6 & 10.2 & 13.3 & 32 & 77 & 21 & 2 \\
\hline $\mathrm{AB} 4$ & 2 & 0 & 35.8 & 10.5 & 9.3 & 30 & 77 & 21 & 3 \\
\hline $\mathrm{AB} 5$ & 2 & 0 & 41.3 & 12.3 & 8.8 & 22 & 76 & 23 & 2 \\
\hline $\mathrm{AB} 6$ & 3 & 0 & 45.5 & 13.7 & 13.6 & 12 & 77 & 19 & 4 \\
\hline $\mathrm{AB} 7$ & 3 & & 48.5 & 14.3 & 13.4 & 11 & 78 & 19 & 3 \\
\hline AB 8 (bedrock) & 4 & & 5 & 1.5 & & 85 & & & \\
\hline TZ 54 (chalk) & sur & ace & 8.5 & 3.2 & 5.6 & 74 & 64 & 25 & 11 \\
\hline $\begin{array}{c}\text { Sample } \\
\text { No. }\end{array}$ & $\begin{array}{r}\text { Mag } \\
\text { suscep } \\
\chi(1 / \mathrm{kg}\end{array}$ & $\begin{array}{l}\text { netic } \\
\text { tibility } \\
* \text { E-3 }\end{array}$ & $\begin{array}{c}\text { Specific } \\
\text { surface area } \\
\text { in } q \mathbf{m} / \mathbf{g}\end{array}$ & $\begin{array}{c}\text { Micropore } \\
\text { surface area } \\
\text { in } \mathbf{q m} / \mathrm{g}\end{array}$ & $\mathrm{Ba} / \mathrm{Sr}$ - ratio & $\begin{array}{c}\text { Base acc. } \\
\text { index* }\end{array}$ & $\begin{array}{c}\mathrm{Fe} \\
(\mathrm{d} / \mathrm{t})^{* *}\end{array}$ & $\begin{array}{c}\text { Mn } \\
(d / t))^{* *}\end{array}$ & $\begin{array}{c}\text { Oxalate } \\
\text { extractable } \\
\text { aluminium } \\
(\mathrm{mg} / \mathrm{g})\end{array}$ \\
\hline$\overline{\mathrm{AB}} 1$ & & 0 & 43 & 13 & 1.6 & 1.7 & 0.32 & 0.76 & 1.2 \\
\hline $\mathrm{AB} 2$ & & 6 & 44 & 14 & 1.6 & 1.5 & 0.24 & 0.51 & 1.2 \\
\hline $\mathrm{AB} 3$ & 15 & 7 & 60 & 18 & 2.2 & 2.6 & 0.34 & 0.8 & 1.6 \\
\hline $\mathrm{AB} 4$ & 16 & 2 & 77 & 21 & 2.1 & 2.9 & 0.23 & 0.62 & 1.5 \\
\hline AB 5 & 18 & 2 & 90 & 25 & 2.6 & 4.8 & 0.18 & 0.5 & 1.8 \\
\hline $\mathrm{AB} 6$ & 21 & 1 & 107 & 31 & 2.9 & 7.7 & 0.26 & 0.77 & 2.2 \\
\hline $\mathrm{AB} 7$ & 23 & 8 & 109 & 31 & 2.1 & 7.6 & 0.24 & 0.76 & 2.1 \\
\hline AB 8 (bedrock) & & & & & 0.1 & 0.2 & & & \\
\hline TZ 54 (chalk) & 1 & 0 & & & 0.3 & 0.3 & 0.53 & 0.18 & 0.03 \\
\hline $\begin{array}{c}\text { Sample } \\
\text { No. }\end{array}$ & $\begin{array}{l}\mathrm{C}_{\text {org }} \\
(\%)\end{array}$ & $\mathbf{T i} / \mathbf{Z r}$ & Illite & Vermiculite & Montmorillonite & Kaolinite & Chlorite & Palygorskite & Quartz \\
\hline$\overline{\mathrm{AB}} 1$ & 1.2 & 30 & $\mathrm{x}$ & $\mathrm{xx}$ & $\mathrm{xxx}$ & $\mathrm{xxx}$ & & & $\mathrm{xx}$ \\
\hline $\mathrm{AB} 2$ & 1 & 29 & $\mathrm{x}$ & $\mathrm{xx}$ & $\mathrm{xxx}$ & $\mathrm{xxx}$ & & & $\mathrm{xx}$ \\
\hline $\mathrm{AB} 3$ & 1.5 & 29 & $\mathrm{x}$ & $\mathrm{xx}$ & $\mathrm{xxx}$ & $\mathrm{xxx}$ & & & $\mathrm{xx}$ \\
\hline $\mathrm{AB} 4$ & 0.8 & 30 & $\mathrm{xx}$ & $\mathrm{xxx}$ & $\mathrm{xxx}$ & $\mathrm{xxx}$ & $\mathrm{x}$ & & $\mathrm{xx}$ \\
\hline $\mathrm{AB} 5$ & 0.5 & 31 & $\mathrm{xx}$ & $\mathrm{xx}$ & $\mathrm{xxx}$ & $\mathrm{xxx}$ & $\mathrm{x}$ & & $\mathrm{xx}$ \\
\hline $\mathrm{AB} 6$ & 0.7 & 32 & $\mathrm{xx}$ & $\mathrm{xx}$ & $\mathrm{xxx}$ & $\mathrm{xxx}$ & $\mathrm{x}$ & & $\mathrm{xx}$ \\
\hline $\mathrm{AB} 7$ & 0.7 & 30 & $\mathrm{xx}$ & $\mathrm{xx}$ & $\mathrm{xxx}$ & $\mathrm{xxx}$ & $\mathrm{x}$ & & $\mathrm{xx}$ \\
\hline AB 8 (bedrock) & & 11 & $\mathrm{x}$ & & $\mathrm{xxx}$ & $\mathrm{x}$ & & $\mathrm{xx}$ & $\mathrm{xx}$ \\
\hline TZ 54 (chalk) & 1 & 23 & $\mathrm{x}$ & & $\mathrm{xxx}$ & $\mathrm{xxx}$ & & & $\mathrm{xx}$ \\
\hline
\end{tabular}

$\mathrm{x}$ - traces; $\mathrm{xx}$ - present; $\mathrm{xxx}$ - abundant

The limited bulk soil analyses of our second test site (at the street to Hubras) yielded results again confirming the field impression (Table 2). In contrast to the first test site, this profile shows an increasing content of calcium carbonate towards the bottom and a very clay-rich texture as would be expected according to the residual theory.

\subsection{Micromorphology results}

Optical investigation of our first test site at the ABprofile showed more or less unaltered biogenic calcareous rock in the lowest sample AB DS0 that was taken at the transition from white to greyish limestone. It contains many foraminifera skeletons as well as some shells together with small calcium carbonate plates that might have formed during re-crystallization processes. Clay and iron are present in a reddish-brown matrix that occasionally contains allochthonous material such as probably primary detrital biotite altered to vermiculite; a post-sedimentary input and transport through fissures in the rock seems unlikely (Figure 6). But most importantly, close-ups of the microfossils under a SEM showed how the rims of these structures are being replaced by clay, though still in an initial stage (Figure 7a).

In the second sample from the AB-profile (AB DS1), taken at the transition from greyish rock to greyish-red saprolite, the replacement progressed significantly. There are fewer microfossils in general, and fewer in the initial stage of replacement (Figure 7b). The clay matrix dominates 
Table 2: Bulk soil analyses of the profile at the Hubras street cut.

\begin{tabular}{cccccc}
\hline $\begin{array}{c}\text { Sample } \\
\text { No. }\end{array}$ & $\begin{array}{c}\text { Sampling } \\
\text { depth }[\mathrm{cm}]\end{array}$ & $\mathrm{CaCO}_{\mathbf{3}} \%$ & Clay \% & Silt \% & Sand \% \\
\hline AB 17 & 20 & 18 & 70 & 26 & 3 \\
AB 18 & 40 & 19 & 76 & 22 & 2 \\
AB 19 & 60 & 22 & 74 & 24 & 2 \\
AB 20 & 80 & 40 & 74 & 23 & 3 \\
AB 21 & 100 & & & & \\
(bedrock) & & & & & \\
\hline
\end{tabular}
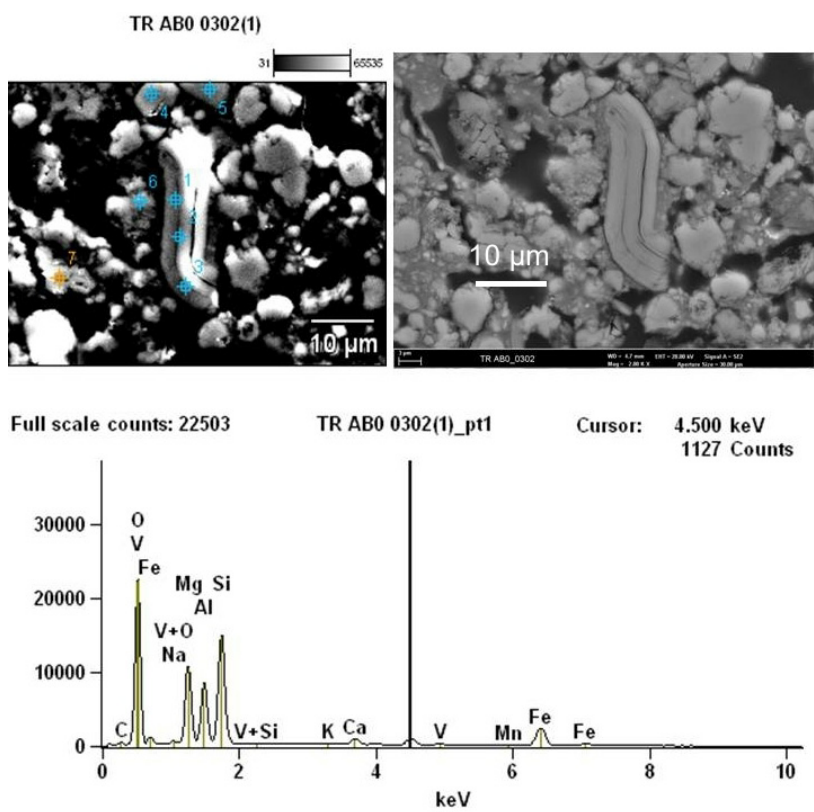

Figure 6: Vermiculite lath replacing a former biotite by cation exchange of $\mathrm{K}$ and $\mathrm{Mg}$. Sample AB DS0, AB-profile. EDS-point analysis at point one in the centre of the vermiculite lath (pt1, see numbered circles in the upper left picture) confirms the interpretation (see presence of elements in the lower graph). Points 2-7 in the SEM-picture were analysed, but are not presented here as they did not reveal additional information. The scale bar measures $10 \mu \mathrm{m}$.

spatially and also the pore volume increased significantly. In the pores, recrystallization of calcite plates took place (Figure 7c).

In the third sample from the AB-profile (AD DS2), taken at the transition from greyish- red saprolite to the fully developed Terra Rossa, the replacement has advanced further. Microfossils are difficult to detect and seem merely present as "shadows" of clays still preserving the former fossil shapes, and apparently there was additional precipitation of iron along cracks. One partially replaced microfossil suggests that the replacement starts along the outer rim, producing a serrated structure as described by Merino and Banerjee (2008), and along fissures (Figures $7 \mathrm{~d}$ and 8).

Calcium carbonate plates are reduced in number, and there are indications of calcium carbonate solution and neoformation. Replacement processes also seem to take place in larger calcite crystals which are surrounded by clay films apparently preserving the original crystal shape of the mineral. Dissolution voids inside the remaining calcite could have been formed by acidic solutions, which might be connected with the occurrence of $\mathrm{HCO}_{3}^{-}$and $\mathrm{H}^{+}$during replacement processes as suggested by the model of Merino and Banerjee (2008). It seems possible that replacement sometimes follows the "blueprint" of the calcite mineral structure. Figure 9a shows how a probably dolomitic calcite mineral is gradually being replaced by clay.

Sample "AB DS basalt", taken next to the basalt floater in the "bleached zone", shows partially replaced microfossils as well, but no indication of a contribution from the basalt to soil formation. We could observe neither typical basalt minerals nor structures that could be relics of basalt replacement. Clearly, the investigated sample does not represent the immediate transition between red soil and basaltic boulder. It might also be an indication of much slower replacement reactions in basalt compared to limestone.

Sample "Hubras street cut DS", taken at the rock-soil transition of our second test site at the Hubras street cut, showed a matrix of strongly weathered biogenic limestone with many microfossils mixed with reddish-brown clay. Despite the absence of a "bleached zone", some of the microfossils show evidence of replacement processes, consisting partially of calcium carbonate and partially of clay (Figure 9b). Again, no detrital clay could be observed in the adjacent soil fissures.

A close-up of the partially replaced microfossil is shown in Figure 10. The 10-fold enlargement of the clay-calcite contact zone at the outer rim of the microfossil shows the replacement reaction front as a dark, jelly-like mass. This amorphous mass irregularly penetrates the calcite body and replaces it, leaving isolated calcite fragments at the beginning until these fragments are also replaced.

Finally, the two samples from the third test site, "Q rock transition 1" and "Q rock transition 2", taken at the apparently "sharp" transition between cemented wadi gravels and a Terra Rossa paleosol in Wadi Queilbeh, also contained "shadows" of partially replaced microfossils (Figure 10b). The rock at this test site consists of well-rounded calcite grains embedded in secondary calcium carbonate, and the primary calcite grains contain microfossils that are partially replaced by clay. Contrary to our expectation, the dissolution of the rock seems not to preferentially start with the softer cement, but occurs along a straight reaction front that gives the impression of a very "sharp" transition between soil and rock.

\section{Discussion}

The results of bulk soil analysis largely support the field impression that weathering at the first test site is strongest in the lower part of the profile. Although the $\mathrm{Fe}_{(\mathrm{d} t \mathrm{t})}$ and $\mathrm{Mn}_{(\mathrm{d} / \mathrm{t})}$ 

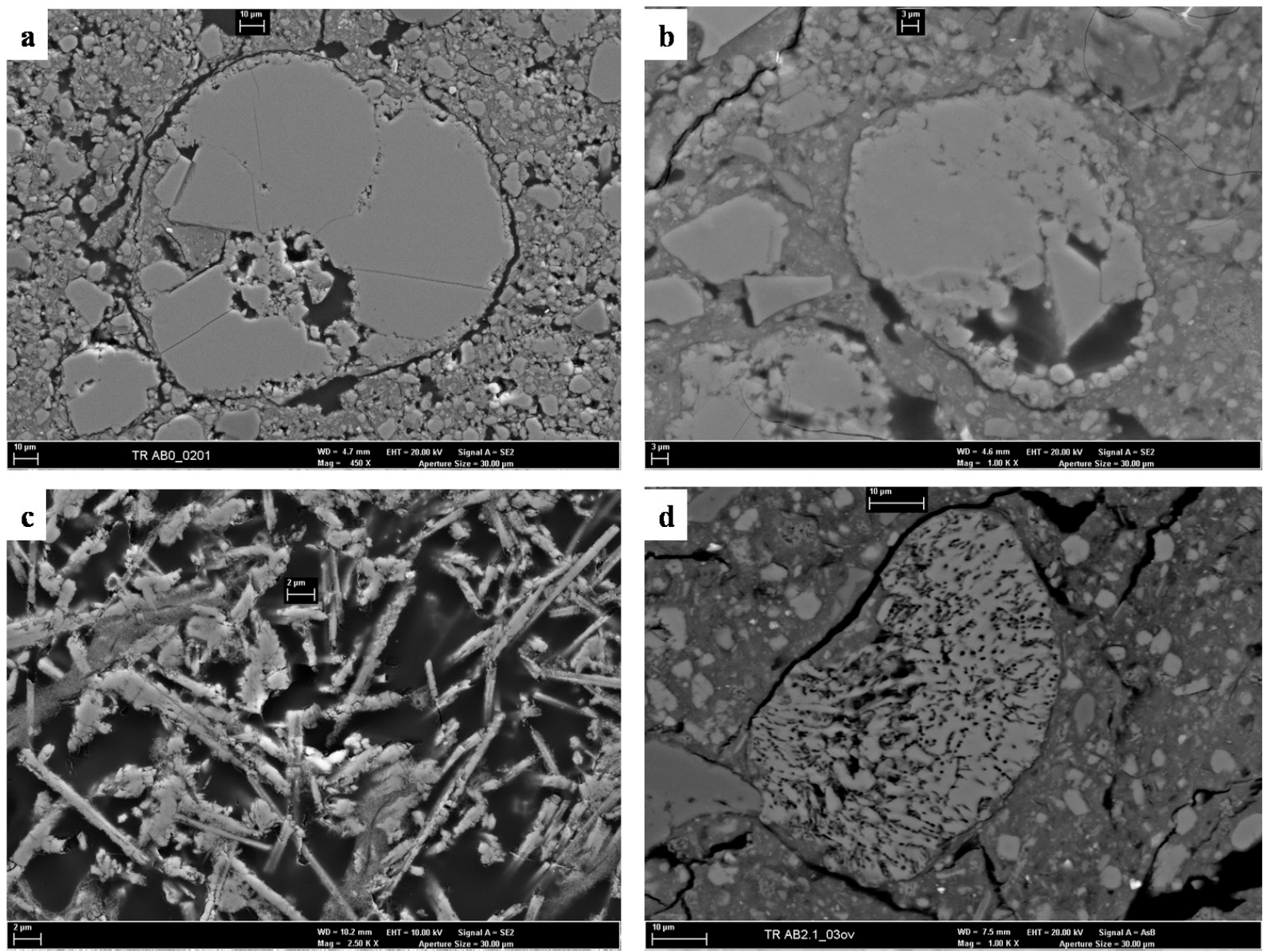

Figure 7. a) Microfossil starting to be replaced by clay from the outer rim, and from small cracks. Sample AB DS0, AB-profile. The scale bar measures $10 \mu \mathrm{m}$. b) Microfossil in the initial stage of replacement. Sample AB DS1, AB-profile. The scale bar measures $3 \mu \mathrm{m}$. c) Calcite neoformation in voids of sample AB DS1, AB-profile. The scale bar measures $2 \mu \mathrm{m}$. d) Serrated structure of a partially replaced microfossil in sample AB DS2, AB-profile. The scale bar measures $10 \mu \mathrm{m}$.

ratio show no clear tendencies, the increase of silicium, aluminium and dithionite-extractable iron as well as the decrease of $\mathrm{CaCO}_{3}$ point towards stronger pedogenesis in the lower part of the profile. This is further supported by the texture, which becomes finer in the lower part, and by the specific and micropore surfaces and the magnetic susceptibility (Table 1). The specific and micropore surfaces suggest that the lower part of the profile is characterised by a higher porosity, which does not strictly correlate with the clay content and might therefore be related to the lower contents of calcium carbonates. This might, to some degree, explain the distribution of the $\mathrm{Fe}_{(\mathrm{d} / t)}$ and $\mathrm{Mn}_{(\mathrm{d} / t)}$ ratios: the extraction of pre-weathered sedimentary pedogenic iron by sodium dithionite from primary calcium carbonate could play a role, which is also indicated by the high $\mathrm{Fe}_{(\mathrm{d} t)}$-ratio of the chalk sample TZ 54.

Lucke (2008) suggested that iron weathering under drying and wetting cycles in association with organic matter could explain the magnetic enhancement of soils in northern Jordan, which would make the magnetic susceptibility a marker for the intensity of pedogenesis. At our first test site, the magnetic susceptibility increases strongly towards the bottom, supporting the idea of increasing weathering. Since organic matter is present in considerable amounts in the whole profile (and was also evident in form of roots during the sampling), iron weathering, as suggested by Lucke (2008), could have contributed to the magnetic enhancement of the lower part of the profile.

The barium/strontium relationship is a weathering index based on the comparison of a stable with an unstable element. Weathering indices are problematic in areas with partly negative water balances such as Jordan (at the investigated site the water balance is negative in summer, but positive in winter), since the frequent drying of soils may lead to accumulation of cations which are otherwise quickly washed out. Nevertheless the $\mathrm{Ba} / \mathrm{Sr}$-index shows a clear tendency: compared to the source rock, $\mathrm{Ba}$ is enriched in the soil, especially at the bottom. Similarly, a nearly 10 -fold enrichment of $\mathrm{SiO}_{2}$ as compared to the bedrock is present in the lower part of the profile. Such enrichments were interpreted by Yaalon and Ganor (1973) as evidence for the long-range deposition of desert dust, in particular 


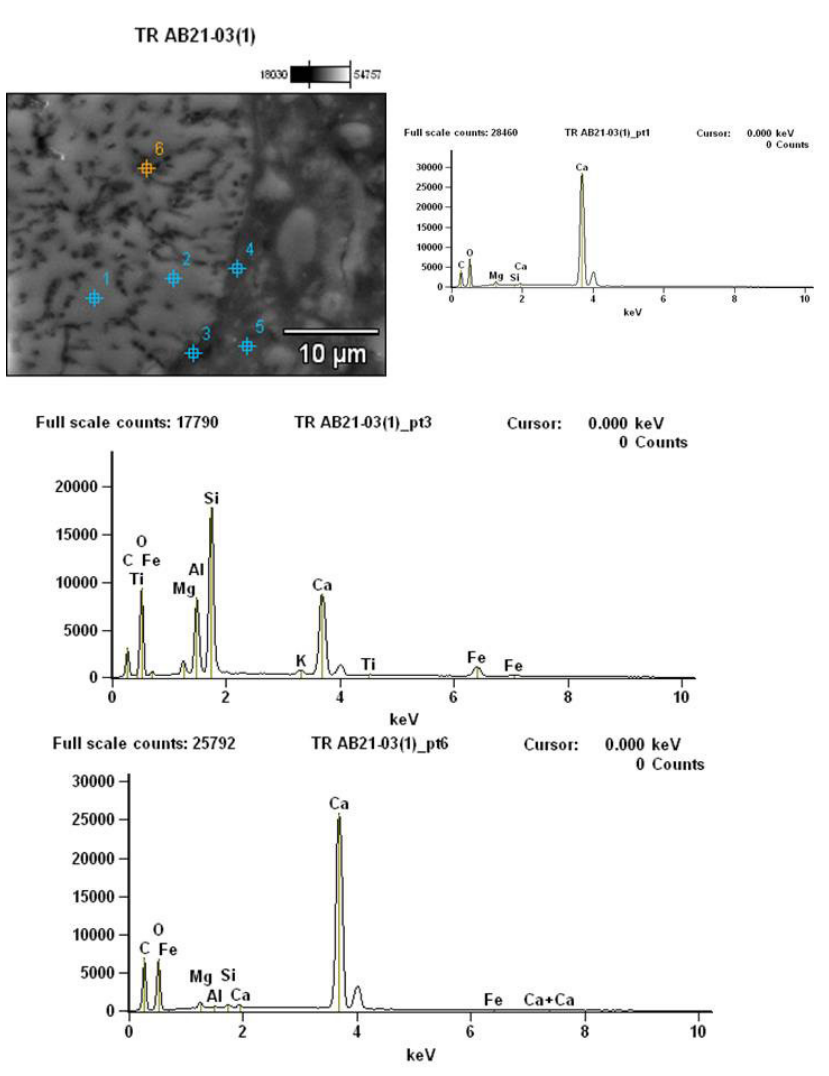

Figure 8: SEM-EDS-analysis of the serrated microfossil presented in Figure $7 \mathrm{~d}$. The results of EDS-analysis of points 1 (upper right), 3, and 6 (below) are presented and show the presence of elements at the respective locations. Note the clay mineral typical elements ( $\mathrm{Si}, \mathrm{Al}, \mathrm{Mg}, \mathrm{Fe})$ at the immediate, serrated outer rim (pt.3), and especially traces of them inside the fossil (pt. 6). In contrast, point one (pt1, see upper right) represents the calcite body.

clay minerals.

Lucke (2008) had concluded, from the comparison of soils on different bedrocks in the investigation area, that there must have been external additions which contained less titanium than basalt, but more than limestones, because Ti (as most other cations) was depleted in basalt soils, but enriched in limestone soils. Zirconium, in contrast, was enriched in all studied soils compared to the rocks (Lucke, 2008). Principally, accumulation during weathering should lead to a relative enrichment of all cations, but should mirror the primary chemical composition. Apart from this, the mineral structure and resistivity against weathering is an important secondary factor in this consideration. Zircon, as one of the most resistant minerals against any type of weathering, should always be enriched during pedogenesis. In basaltic rocks, zirconium is rather rare, but has a higher concentration than in limestone. In limestone, it will nearly exclusively be found in sandy interlayers. Titanium, on the other hand, is an element of several major mineral components in basic rocks, such as rutile, biotite, amphiboles, pyroxenes, and magnetite. Only the Ti-rich magnetite shows a high weathering resistivity. Therefore, the weathering profile of a basaltic soil is characterized by decreasing Ti contents, even if some Ti might have been added by aeolian influx of phyllosilicates like muscovite, biotite, or chlorite. For a weathering limestone, in turn, aeolian input would be essential to increase the Ti contents, and the homogeneous $\mathrm{Ti} / \mathrm{Zr}$-ratio over the profile of our first test site points towards a fairly constant deposition of Ti during the formation of the soil. In this context, the increasing values of silicium and the base accumulation index towards the bottom are unlikely the result of varying foreign material, but are probably connected with stronger pedogenesis and/or clay formation. Clay formation due to weathering, or clay neoformation due to isovolumetric replacement, could explain the strongly increasing amounts of silicium, aluminium, and base accumulation in the lower part of the profile.

The presence of partially replaced microfossils in the rock-soil transition zones of all three test sites clearly shows that metasomatic processes contributed to the development of all studied Terrae Rossae. With regard to the third test site in Wadi Queilbeh, it still seems possible that a major part of the Terra Rossa paleosol at the bottom formed out of allochthonous sediments as assumed. But again, the presence of microfossil shadows at the rock-soil transition zone indicates that isovolumetric replacement affected the development of this soil too. As a striking feature, the reaction front at the rock-soil contact zone was not characterized by a discontinuity as, for example, could be caused by the deposition of allochthonous (fluvial, colluvial) material, or by preferential solution of the softer parts of the cemented gravel. Here, both the harder and softer parts of the rock seem to be replaced uniformly.

A key question of isovolumetric replacement is how to evaluate whether the clay is authigenic. Bronger and Sedov (1997) had earlier observed microfossils partially consisting of clay and suggested a detrital origin for such structures by diffusion of clay into the rock pores after suspension in the soil water. This, however, is not the case at our test sites as illustrated by Figures 10a and 10b: the clay of the partially replaced microfossils does not show a crystalline structure as would be expected after precipitation out of the rock-soil water, but appears merely like a newly-formed jelly-like mass, which fits to the clay minerals that Jahn (1995) found amorphous to X-ray diffraction. Additionally, neo-formation of calcite plates could be observed in voids. Finally, preserved structures of calcite crystals, shown in Figure 10, can hardly be explained by this theory.

The clay matrix in our thin sections partly bears phyllosilicates, which, on the first glance, seem to match what Merino and Banerjee (2008) described as "very large clay crystals". They suggested that the presence of large clay crystals can be interpreted as proof of authigenic in-situ formation, but which cannot be confirmed by our study. In contrast, the close-up with the SEM revealed:

i) A jelly-like structure of the replacing clay matrix which we consider a far more likely result of the pressure- 


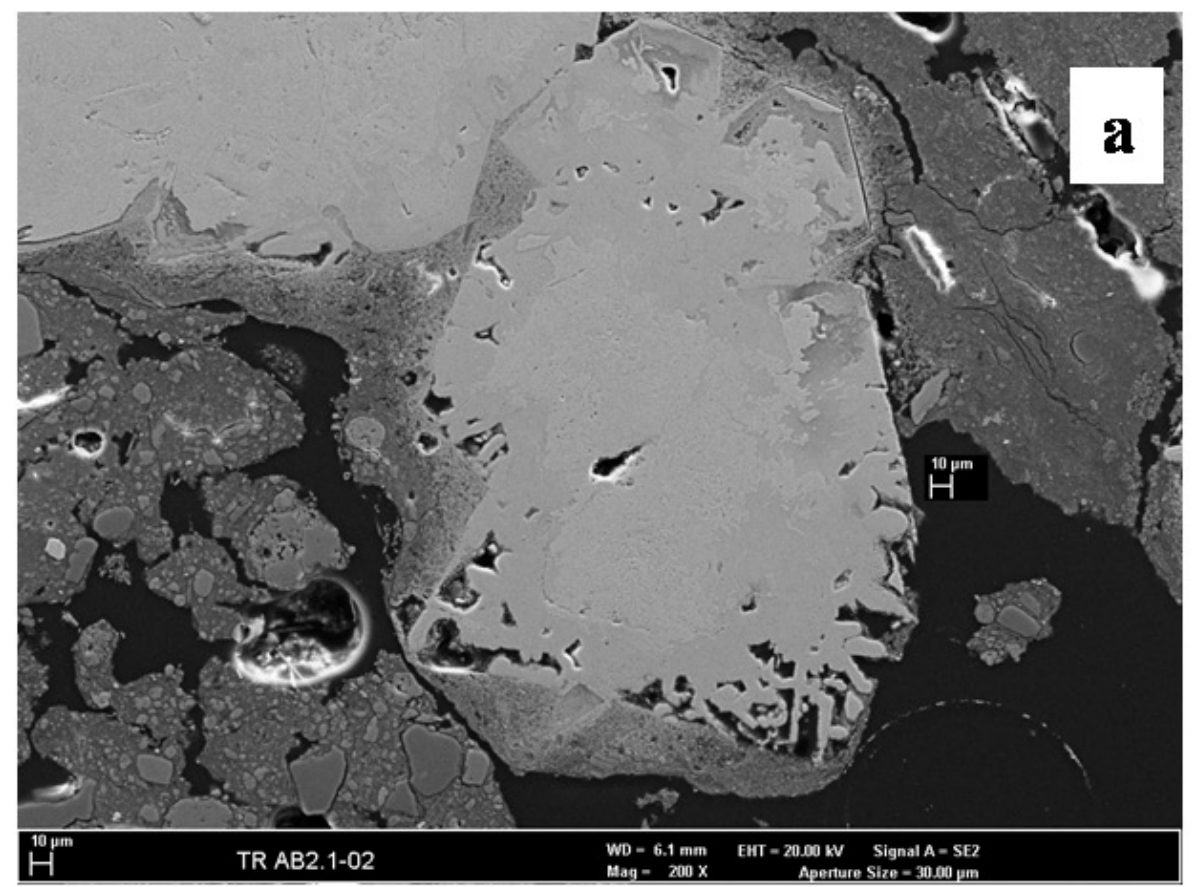

\section{hubras1(2)}
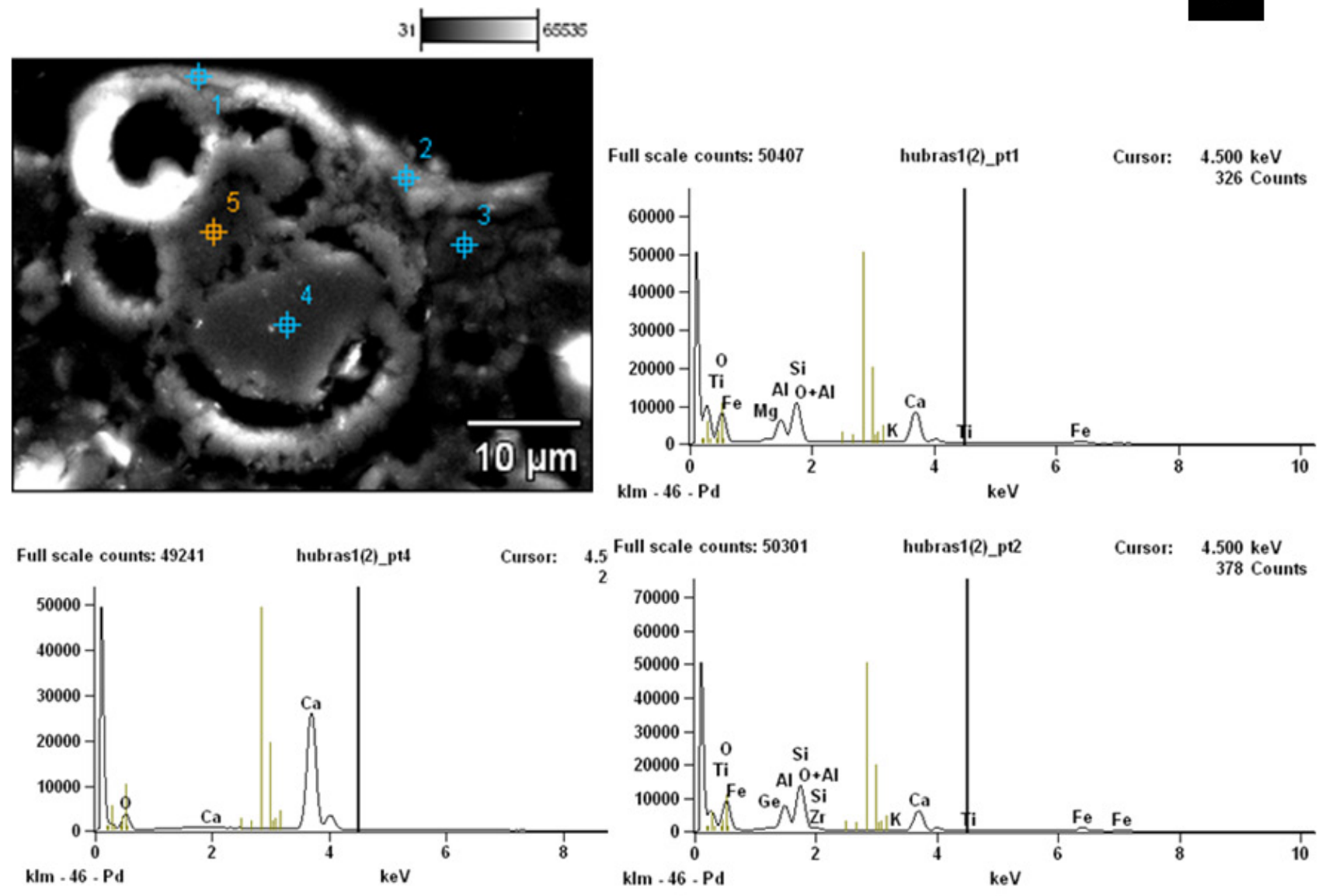

Figure 9. a) Partially replaced calcite mineral. Note how the outer form of the calcite mineral is being traced by the replacing clay, and how dissolution voids appear at the rim. Sample AB DS2, AB-profile. The scale bar measures $10 \mu \mathrm{m}$. b) A selection of EDS-point analyses of a marginally replaced microfossil in sample "Hubras street cut DS". The element distributions at points 1, 4, and 6 in the SEM-picture are presented with the graphs. In points 1 and 2, which show the composition of the clayey film, Ca peaks as signals of the calcite shell of a foraminifera were also detected. These structures fall below the effective resolution of the electron beam. In contrast, point 4 shows the composition of the unaltered calcite body. 

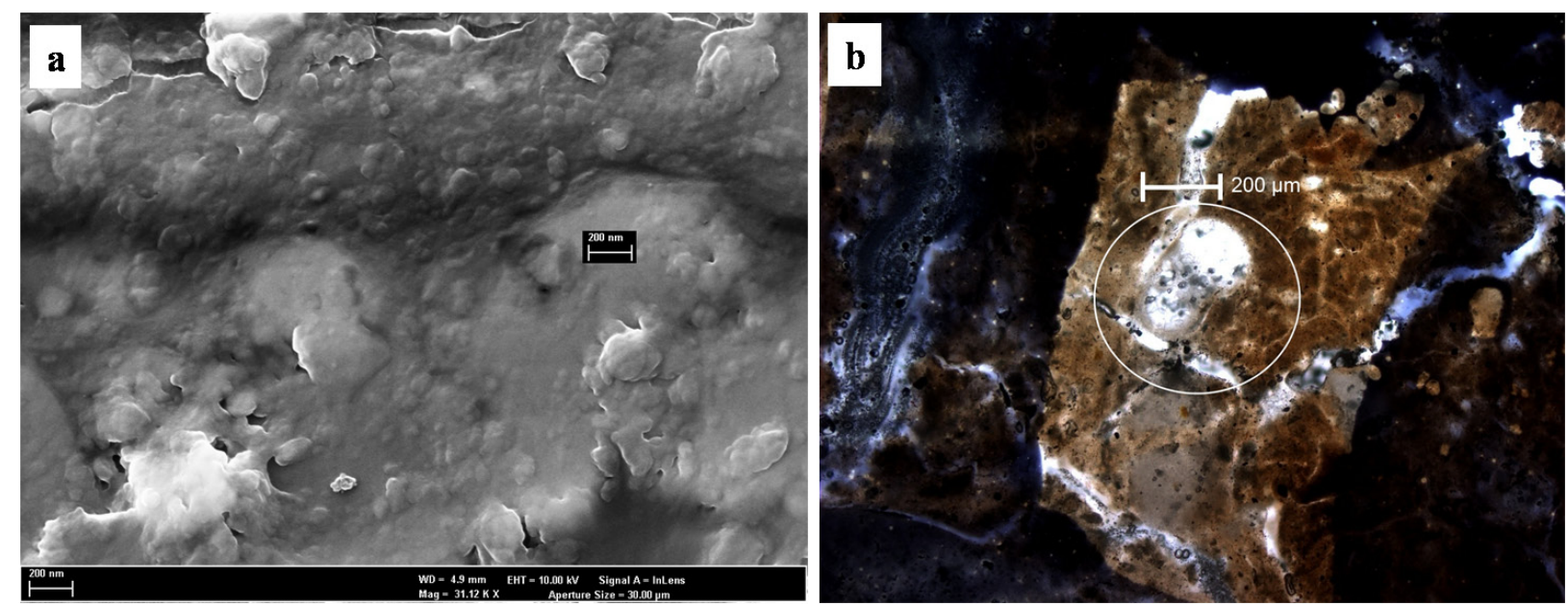

Figure 10. a) Close-up of the lobate clay-calcite reaction front of the microfossil shown in Figure 9b. The replacement reaction front looks like a dark band. The scale bar measures $200 \mathrm{~nm}$. b) Partially replaced microfossil (light, bulbous body marked with circle) in the rock-soil transition zone of the Wadi Queilbeh paleosol. The scale bar measures $200 \mu \mathrm{m}$. Sample "Q rock transition 2", Cross Polarized observation

driven replacement process than a large mineral which should only form when sufficient space is available. In this context, the significant increase of Alo towards the reaction front supports the conclusion that a considerable amount of amorphous clay minerals is present in the lower part of the profile which could not be identified by X-ray diffraction due to quantification with the Rietveld method.

ii) Relatively large phyllosilicates (some tens of microns) that sparsely occur throughout the $\mathrm{AB}$ profile are of detrital origin, most probably derived from some former sandy or silty intercalations within the carbonate layers. Some of them still show a former biotite composition with higher iron and potassium contents, while others were completely altered and changed to clay minerals as the vermiculite lath shown in figure 6.

Related to the degree of replacement, microfossils are most intact in the lowest part of the 'bleached zone' at the AB-profile. They are more completely replaced and harder to trace in those zones closer to the fully developed Terra Rossa. Assuming that isovolumetric replacement is the dominant soil formation process near the reaction front, strong weathering of the Terra Rossa should be found near the 'bleached zone' since calcium carbonate should be fully replaced here. To some degree, this is in agreement with the results from the AB-profile. However, the apparent recalcification of the upper part of the profile makes it seem unlikely that the ions driving the replacement are supplied from the top or from allochthonous additions. A more likely source seems to be the bedrock, either directly through bedrock dissolution or by ascending waters, as suggested by Reifenberg (1947).

In this context, one additional factor contributing to the mobility of ions could be the plant cover. Blanck (1915) suggested that the small humus contents of Mediterranean soils were responsible for iron precipitation out of the soil water in the contact zone with the calcareous rock, but this appears unlikely in the light of high contents of calcium carbonate in the upper part of the AB-profile. However, the increasingly strong magnetic susceptibilities at the bottom of the profile suggest that organic material plays a role, as it is involved in the weathering process that can most likely explain the magnetic enhancement. Verboom (2007), Pate et al. (2001), and Verboom and Pate (2001) suggested that some soil and laterite formations might be products of bioengineering by specific plants, for example mallee eucalypts creating clay pavements along their lateral root catchments in sand dunes of Australia. Here, the key elements for the formation of the clays, like $\mathrm{Al}, \mathrm{Fe}$, and $\mathrm{Si}$, were supplied by xylem transport (Verboom et al., 2009). We consider the possibility that some similar process, possibly combined with ascending waters from the underlying limestone (where tree roots can be found which draw water from the rock's fissures), contributes to the formation of the reaction front at the rock-soil transition zone.

The basalt boulders at the rock-soil transition zone in the AB-profile near the Yarmouk valley should be considered at this point. No outcropping basaltic rock has been preserved in the close vicinity of the AB-profile and, although several sheet flows extending from the Djebel al-Arab are located in the surrounding area, especially north of the Yarmouk valley in Syria, there is so far no indication that the basalts (and with them other sediments possibly constituting the main parent material of the Terra Rossa) were transported to the investigated site. Hence, the basalt boulders at the base of the Terra Rossa can probably be explained as "floaters" (Meert et al., 2009), representing remnants of Cretaceous volcanic bombs (Moh'd, 2000), now left over as the most resistant parts. However, a downwards migration during soil formation also appears possible in the light of slickensides and the vertical dynamics of the Terra Rossa.

According to Moh'd (2000), part of the Terrae Rossae occurring in northern Jordan are characterized by a 
"bleached" transition zone as in our AB-profile, and part of these zones locally host basalt boulders. It is thus not an uncommon phenomenon. Also, volcanic bombs occasionally appear in Cretaceous chalks. However, basalts deposited within the limestones and chalks were described by Khoury and Nassir (1982) only for the contact zone between the Muwaqqar Chalk Marl and Umm Rijam Chert Limestone, which are older than the investigated transition zone. In the light of numerous partially replaced microfossils in the surrounding "bleached zone", we tentatively count the presence of the basalt "floaters" as further indication of isovolumetric replacement as described by Meert et al. (2009). This should be clarified in further geomagnetic studies in order to better understand the connection of the basalts with the limestone and the Terra Rossa.

\section{Conclusions}

A reaction front, and thus evidence for isovolumetric replacement processes, was present in all investigated soil profiles. In the samples from northern Jordan, isovolumetric replacement seems a more universal process than initially expected. However, this does not mean that other weathering processes do not contribute to Terra Rossa genesis, nor does it clarify the origin of the ions driving the growth of clay minerals. Up to now, it has not been possible to quantify the contribution of isovolumetric replacement to Terra Rossa genesis, and it is possible that it is a rather insignificant process limited to the reaction zone. The presence of partially replaced microfossils does not exclude the presence of processes like dissolution of bedrock by meteoric water or deposition of allochthonous material; our study does not allow quantifying the extent of the possible contribution of these sources to Terra Rossa development at the respective sites. The predominance of one or the other process clearly depends on such variable factors as climate, morphology, and bedrock.

Considering the nearly identical mineralogical compositions and element distribution of Terrae Rossae and underlying bedrocks as found by Leiningen (1930), Bronger et al. (1984), Moresi and Mongelli (1988), Shijie et al. (1999), Ji et al. (2004a, 2004b), and Temur et al. (2009), it seems clear that at some sites Terrae Rossae resemble the limestone residue. At sites characterized by allochthonous additions the possible contribution of isovolumetric replacement should be evaluated. However, in light of the re-calcified upper part of the AB-profile, it seems unlikely that allochthonous additions are the only possible source for ions driving the growth of clay minerals. These could probably also come from bedrock dissolution or from ascending waters as suggested by Reifenberg (1947). Bio-engineering by specific plants, such as reported for mallee eucalypts on sand dunes in Australia (Verboom et al., 2009), should be considered as another possible source for ion supply.

Blanck (1926) stated that some Terra Rossa soils are doubtless the result of limestone dissolution (which he suggested be called "rote Erden" in contrast to "Roterden"), but which in his opinion mislead the investigators because they would not consider the possible contribution of metasomatism. In this context, the presence of isovolumetric replacement in the formation of some Terrae Rossae suggests that we should re-consider some earlier interpretations of their paleoenvironmental significance. For example, Terrae Rossae in Central Europe were sometimes considered very old soils, products of very long dissolution processes and occurring nearly exclusively on old land surfaces that were not glaciated (KA 5, 2005). If isovolumetric replacement can however be confirmed for those sites, much shorter formation processes seem possible. This would be in agreement with reports of Alfisols with rubefied Bt horizons developed on calcareous Pleistocene gravels in the northern forelands of the Alps (Schwertmann et al., 1982). As suggested by Blanck et al. (1928), both fossil and recent formation of red soil horizons in Central Europe would be possible if metasomatic genesis was assumed.

\section{Acknowledgements}

This research was supported by a research grant by the German Research Foundation (DFG, grants no. SCHM 2107/2-1, BA 1637/4-1), which we gratefully acknowledge. We would like to thank Enrique Merino, Sergey Sedov, Elisabeth Solleiro, Alexander Tsatskin, Dan Yaalon, William Verboom and Hector Cabadas Báez for fruitful discussions on our findings and recommendations to improve the manuscript.

\section{References}

Bender, F., 1974, Geology of Jordan: Berlin, Germany, Gebrüder Bornträger, $196 \mathrm{p}$.

Blanck, E., 1915, Kritische Beiträge zur Entstehung der MediterranRoterde: Die Landwirtschaftlichen Versuchsstationen, 87, 251-314.

Blanck, E., 1916, Ein Beitrag zur Entstehung der Mediterran-Roterde vom Standpunkt kolloidchemischer Bodenforschung und klimatischer Bodenzonenlehre: Geologische Rundschau, 7, 57-62.

Blanck, E., 1926, Vorläufiger Bericht über die Ergebnisse einer bodenkundlichen Studienreise im Gebiet der südlichen Etschbucht und des Gardasees: Chemie der Erde, 2, 175-208.

Blanck, E., Oldershausen, E. von, 1936, Über rezente und fossile Roterde(Terra rossa-) Bildung, insbesondere im Gebiet der südlichen Frankenalb, des Altmühltalgebirges: Chemie der Erde, 10, 1-66.

Blanck, E., Scheffer, F., 1926, Rote Erden im Gebiet des Gardasees: Chemie der Erde, 2, 149-156.

Blanck, E., Passarge, S., Rieser, A., 1926, Über, Über Krustenböden und Krustenbildungen wie auch Roterden, insbesondere ein Beitrag zur Kenntnis der Bodenbildungen Palästinas: Chemie der Erde, 2, 348-395.

Blanck, E., Giesecke, F., Rieser, A., Scheffer, F., 1928, Über die Entstehung der Roterde im nördlichsten Verbreitungsgebiet ihres Vorkommens: Chemie der Erde, 3, 44-90. 
Bronger, A., Bruhn-Lubin, N., 1997, Paleopedology of Terrae rossae - Rhodoxeralfs from Quaternary calcarenites in NW Morocco: Catena, 28, 279-295.

Bronger, A., Ensling, J., Kalk, E., 1984, Mineralverwitterung, Tonmineralneubildung und Rubefizierung in Terrae Calcis der Slowakei: Catena, 11, 115-132.

Bronger, A., Sedov, S., 1997, Origin and redistribution of pedogenic clay in Terrae Rossae from Quaternary calcarenites in coastal Morocco, in Shoba, S., Gerasimova, M., Miedema, R. (eds.), Soil Micromorphology, Studies on soil diversity, diagnostics, dynamics: Moscow \& Wageningen, Russia \& The Netherlands, 59-66.

Cabadas, H., Solleiro, E., Sedov, S., Pi, T., Alcalá, J., 2010, The Complex Genesis of Red Soils in Peninsula de Yucatán, Mexico: Mineralogical, Micromorphological and Geochemical Proxies: Eurasian Soil Science, 43, 1439-1457.

Cabadas-Báez, H., Solleiro-Rebolledo, E. Sedov, S., Pi-Puig, T., GamaCastro, J., 2010, Pedosediments of karstic sinkholes in the eolianites of NE Yucatán: A record of Late Quaternary soil development, geomorphic processes and landscape stability: Geomorphology, $122,323-337$.

Danin, A., Gerson, R., Marton, K., Garty, J., 1982, Patterns of limestone and dolomite weathering by lichens and blue-green algae and their palaeoclimatic significance: Palaeogeography, Paleoclimatology, Paleaoecology, 37, 221-233.

Delgado, R., Martín-García, J., Oyonarte, C., Delgado, G., 2003, Genesis of the terrae rossae of the Sierra Gádor (Andalusia, Spain): European Journal of Soil Science, 54, 1-16.

DIN 19683, Deutsches Institut für Normung, 1973, Blatt 1-3, Physikalische Laboruntersuchungen, Bestimmung der Korngrößenzusammensetzung nach Vorbehandlung mit Natriumpyrophosphat: Berlin, Germany, Beuth Verlag.

DIN 51001, Deutsches Institut für Normung, 2003, Allgemeine Arbeitsgrundlagen zur Röntgenfluoreszenz-Analyse (RFA) sowie Beiblatt 1 (Übersicht stoffgruppenbezogener Aufschlussverfahren zur Herstellung von Proben für die RFA): Berlin, Germany, Beuth Verlag.

Durn, G., Ottner, F., Slovenec, D., 1999, Mineralogical and geochemical indicators of the polygenetic nature of Terra Rossa in Istria, Croatia: Geoderma, 91, 125-150.

Feng, J.-L., Zhu, L.-P., 2009, Origin of terra rossa on Amdo North Mountain on the Tibetan plateau, China: Evidence from quartz: Soil Science and Plant Nutrition, 55, 407-420.

González Martín, J., Rubio Fernández, V., García Giménez, R., Jiménez Ballesta, R., 2007, Red palaeosols sequence in a semiarid Mediterranean environment region: Environmental Geology, 51, 1093-1102.

Jahn, R., 1995, Ausmaß äolischer Einträge in circumsaharischen Böden und ihre Auswirkungen auf Bodenentwicklung und Standortseigenschaften: Stuttgart, Germany, Hohenheimer Bodenkundliche Hefte 23, Ph.D. Thesis, 213 p.

Ji, H., Wang, S., Ouyang, Z., Zhang, S., Sun, C., Liu, X., Zhou, D., 2004a, Geochemistry of red residua underlying dolomites in karst terrains of Yunnan- Guizhou Plateau. I. The formation of the Pingba profile: Chemical Geology, 203, 1-27.

Ji, H., Wang, S., Ouyang, Z., Zhang, S., Sun, C., Liu, X., Zhou, D., 2004b, Geochemistry of red residua underlying dolomites in karst terrains of Yunnan- Guizhou Plateau. II. The mobility of rare elements during weathering: Chemical Geology, 203, 29-50.

KA 5, 2005, Ad-hoc Arbeitsgruppe Boden, Bodenkundliche Kartieranleitung: Stuttgart, Germany, E. Schweizerbart, 438 p.

Khoury, H., Nassir, S., 1982, High temperature mineralisation in the bituminous limestone in Maqarin area, N. Jordan: Neues Jahrbuch für Mineralogie-Abhandlungen, 144-2, 197-213.

Leiningen, W., Graf zu, 1915, Ueber die Einflüsse von äolischer Zufuhr für die Bodenbildung: Mitteilungen der Geologischen Gesellschaft zu Wien, 7, 139-177.

Leiningen, W., Graf zu, 1930, Die Roterde (Terra Rossa) als Lösungsrest mariner Kalkgesteine: Chemie der Erde, 4, 178-187.
Lijun, Z., Jingyang, L., 2002, Metasomatic Mechanism of WeatheringPedogenesis of Carbonate Rocks: I. Mineralogical and MicroTextural Evidence: Chinese Journal of Geochemistry, 21, 334-339.

Lucke, B., 2008, Demise of the Decapolis. Past and Present Desertification in the Context of Soil Development, Land Use, and Climate: Saarbrücken, Germany, VDM., 2007, http://opus.kobv.de/btu/ volltexte/2007/343/

Meert, J.G., Pruett, F.D., Merino, E., 2009, An "Inverse Conglomerate" Paleomagnetic Test and Timing of In Situ Terra Rossa Formation at Bloomington, Indiana: Journal of Geology, 117, 126-138.

Merino, E., Banerjee, A., 2008, Terra Rossa Genesis, Implications for Karst, and Eolian Dust: A Geodynamic Thread: The Journal of Geology, 116, 62-75.

Moh'd, B., 2000, The Geology of Irbid and Ash-Shuna Ash Shamaliyya (Waqqas). Map Sheets No. 3154-II and 3154-II. Bulletin 46, Amman, The Hashemite Kingdom of Jordan, Natural Resources Authority, Geology Directorate, Geological Mapping Division.

Molinaroli, E., 1996, Mineralogical characterization of Saharan dust with a view to its final destination in Mediterranean sediments, in Guerzoni, S., Chester, R. (eds.), The impact of desert dust across the Mediterranean: Dordrecht, The Netherlands, Kluwer Academic Publishers, 153-162.

Moresi, M., Mongelli, G., 1988, The relation between the Terra Rossa and the carbonate-free residue of the underlying limestones and dolostones in Apulia, Italy: Clay Minerals, 23, 439-446.

Muhs, D., 2001, Evolution of Soils on Quaternary Reef Terraces of Barbados, West Indies: Quaternary Research, 56, 66-78.

Muhs, D.R., Budahn, J., Prospero, J.M., Carey, S.N., 2007, Geochemical evidence for African dust inputs to soils of western Atlantic islands: Barbados, the Bahamas and Florida: Journal of Geophysical Research, 112.

Muhs, D., Budahn, J., Avila, A., Skipp, G., Freeman, J., Patterson, D., 2010, The role of African dust in the formation of Quaternary soils on Mallorca, Spain and the implications for the genesis of Red Mediterranean soils: Quaternary Science Reviews, 29, 2518-2543.

Pate, J., Verboom, W., Galloway, P., 2001, Co-occurrence of Proteaceae, laterite and related oligotrophic soils: coincidental associations or causative inter- relationships?: Australian Journal of Botany, 49, $529-560$.

Prognon, F., Cojan, I., Kindler, P., Thirdy, M. Demange, M., 2011, Mineralogical Evidence for a local volcanic origin of the parent material of Bermuda Quaternary paleosols: Quaternary Research, $75,256-266$

Reifenberg, A., 1927, Über die Rolle der Kieselsäure als Schutzkolloid bei der Entstehung mediterraner Roterden: Zeitschrift für Pflanzenernährung, Düngung, Bodenkunde, 10, 159-186.

Reifenberg, A., 1947, The soils of Palestine: London, U.K., T. Murby, 179 p.

Regny, V. de, 1904, Sull' origine della "terra rossa": Bolletino della Società geologica Italiana, 23, 158.

Rietveld, H., 2010, The Rietveld Method: a retrospection: Zeitschrift für Kristallographie, 225, 545-547.

Ruhe, R., Olson, C., 1980, Clay-mineral indicators of glacial and nonglacial sources of Wisconsinan loesses in Southern Indiana, U.S.A.: Geoderma, 24, 283-297.

Scheffer, F., Schachtschabel, P., 1998, Lehrbuch der Bodenkunde: Stuttgart, Germany, Ferdinand Enke Verlag, 528 p.

Schlichting, E., Blume, H.-P., Stahr, K., 1995, Bodenkundliches Praktikum: Berlin, Germany, Blackwell Wissenschafts-Verlag, 295 p.

Schmidt, M., Lucke, B., Bäumler, R., al-Saad, Z., al-Qudah, B., Hutcheon, A., 2006, The Decapolis region (Northern Jordan) as historical example of desertification? Evidence from soil development and distribution: Quaternary International, 151, 74-86.

Schwertmann, U., Murad, G., Schulze, D.G., 1982, Is there holocene reddening (hematite formation) in soils of axeric temperature areas?: Geoderma, 27, 209-223.

Shijie, W., Hongbing, J., Ziyuan, O., Deqan, Z., Leping, Z., Tingyu, L., 1999 , Preliminary study on weathering and pedogenesis of carbonate rock: Science in China, 42, 572-581. 
Stiles, C., Stensvold, K., 2008, Loess Contribution to Soils Forming on Dolostone in the Driftless Area of Wisconsin: Soil Science Society of America Journal, 72, 650-659.

Temur, S., Orhan, H., Deli, A., 2009, Geochemistry of the Limestone of Mortas Formation and Related Terra Rossa, Seydisehir, Konya, Turkey: Geochemistry International, 47, 67-93.

Verboom, W., Pate, J., 2001, Relationships between cluster root-bearing taxa and laterite across landscapes in southwest Western Australia: an approach using airborne radiometric and digital elevation models: Plant and Soil, 248, 321-333.

Verboom, W., 2007, Bioengineering of soil profiles in semiarid ecosystems of south-western Australia: Influence on patterning of landscapes: Perth, Australia, ASEG, http://www.publish.csiro.au/paper/ ASEG2007ab156.htm

Verboom, W., Pate, J., Aspandiar, M., 2009, Neoformation of clay in lateral root catchments of mallee eucalypts: a chemical perspective: Annals of Botany, 105, 23-36.
Yaalon, D., Ganor, E., 1973, The Influence of Dust on Soils during the Quaternary: Soil Science, 116, 146-155.

Zippe, W., 1854, Einige geognostische und mineralogische Bemerkungen über den Höhlenkalkstein des Karst, in Schmidl, A. (ed.), Die Grotten und Höhlen von Adelsberg, Lueg, Planina und Laas: Vienna, Austria, Pleiades Publishing Ltd., 209-221.

Manuscript received: October 20, 2010

Corrected manuscript received: December 15, 2011

Manuscript accepted: January 10, 2012 